\title{
Medical simulation - a costly but essential teaching tool
}

The introduction of simulators into medical education seems to be an extremely attractive idea for all actors involved in medical care and medical training: the patient may feel safer; trainees may feel more confident; trainers may feel that they have solved the impossible challenge of providing the best care for their patient and at the same time the best education for their trainees; administrators may feel that they are investing in good quality education, able to increase the skills of employees and to prevent future malpractice claims; industry gains a new expensive and demanding market and the researchers gain new subjects to study.

Using "medical simulation education" as a search phrase in an indexed medical library will retrieve more than 9000 published papers on the subject. Based on these findings it seems safe to say that for researchers the use of simulators in medical education has been beneficial. All the other judgements are based on the perceived benefits, and they may be realistic or not as they are based on subjective assumptions. They need definitive answers provided by well designed and conducted studies. One may think that industry is also gaining from selling expensive medical simulators, but we must admit that we have no information about the costs of developing, producing and marketing simulation products. We may still be unable to draw definitive conclusions regarding profits.

Standardising medical education according to the best evidence [1] is a dream not yet become true worldwide, but it has been suggested that maximising trainee participation might be a reasonable goal [2]. In this struggle to standardise medical education, the introduction of medical simulators has accentuated the debates by adding new sets of interventions with poten-

Address for correspondence: Dr. Dan Sebastian Dîrzu Catedra Anestezie-Terapie Intensivă II UMF "Iuliu Hațieganu” Cluj-Napoca Str. Clinicilor 3-5

Cluj-Napoca, România E-mail: dirzudan@gmail.com tially poorly understood effects. At the same time, it has solved what, for years, seemed to be unrealistic an increased trainee participation in practical activities. Simulation provided the impossible: the acceptable opportunity for trainers to fail and potentially to learn from their own mistakes. Also, it provided an opportunity for debriefing, one of the most important aspects of solving clinical scenarios, as it has been suggested that the reactivation of recently acquired information can strengthen memory storage and likely contributes to memory consolidation [3].

Simulation provided reasons to apply new changes in medical educational programs. It is human nature to react to change with different emotions. Both pessimists and optimists may find published reports as arguments to justify any personal belief. They all should base their opinions on measurements. Measurement is the first step that leads to control and eventually to improvement. If you cannot measure something, you cannot understand it. If you cannot understand it, you cannot control it, and if you are unable to control it, you cannot improve it [4]. The expected effects of using simulation in medical education are not yet clearly defined, nor how to best measure those effects. While solving this problem, one measurement alone remains the only undeniable proof of effectiveness for the training programmes: the number of trainees able to receive practical training and the number of trained procedures.

In this context, a laudable initiative by Artyomenko and Nosenko [5] is their published experience using medical simulation to train their obstetrical anaesthesia teams. The article contains a report of a large number of trainees receiving practical training in a large number of clinical scenarios over a short period of time.

Obstetric anaesthesia is a sensitive field as an obstetrical emergency develops fast, sometimes without any previous warning signs, and a minimum of two lives are endangered at the same time. There is not too much time for training during real life situations and there is increased interest to develop simulation scena- 
rios as an opportunity to train both technical and nontechnical skills. Different approaches have been described, from low fidelity simulators [6] for practical skills training to advanced scenarios. Some authors developed scenarios competing for evidence based interventions status sustaining that they are able to increase not only trainee skills, but also patient outcome [7]. While most of other simulation based trainings focus mostly on individual training, when providing training for obstetrical emergencies, team training seems to be of greater importance [8]. The imperative need to train teams adds a supplementary logistical challenge to the equation.

It is hard to estimate the time needed for all the subjects included in the reported study to encounter patients with all the conditions included in the simulation scenarios and to have the proper instructor, at the proper time, nearby to provide guiding during teaching phase and feedback during debriefing. A life time may be not enough. While it seems clear that providing training is better compared with no training at all, the number of trainees receiving training should be a sufficient reason to justify investments in simulation products.

\section{Dan Sebastian Dîrzu, MD}

Assistant Professor - University of Medicine and Pharmacy "Iuliu Hațieganu” Cluj-Napoca, $\mathrm{PhD}$ Candidate - University of Medicine and Pharmacy Târgu Mureş, Romania

\section{Conflict of interest}

Nothing to declare

\section{References}

1. Masoomi R. What is the Best Evidence Medical Education? Res Dev Med Educ [Internet]. 2012 [cited 2017 Apr 10]; 1(1): 3-5. Available from: http://journals.tbzmed.ac.ir/RDME/Manuscript/ RDME-1-3.pdf. DOI: 10.5681/rdme.2012.002

2. Mann K V. Theoretical perspectives in medical education: past experience and future possibilities. Med Educ [Internet]. Blackwell Publishing Ltd; 2011 Jan [cited 2017 Apr 10]; 45: 60-68. Available from: http://onlinelibrary.wiley.com/wol1/doi/ 10.1111/j.1365-2923.2010.03757.x/full. DOI: $10.1111 / \mathrm{j} .1365-$ 2923.2010.03757.x

3. Bridge DJ, Paller KA. Neural correlates of reactivation and retrieval-induced distortion. J Neurosci [Internet]. NIH Public Access; 2012 Aug 29 [cited 2017 Apr 10]; 32(35): 12144 12151. Available from: https://www.ncbi.nlm.nih.gov/pmc/ articles/PMC3459586/. DOI: 10.1523/JNEUROSCI.137812.2012

4. Harrington HJ. Business process improvement: the breakthrough strategy for total quality, productivity, and competitiveness. McGraw-Hill; 1991, 274 p.

5. Artyomenko VV, Nosenko VM. Anaesthesiologists' simulation training during emergencencies in obstetrics. Rom J Anaesth Int Care 2017; 24: 37-40

6. Magee SR, Shields R, Nothnagle M. Low Cost, High Yield: Simulation of Obstetric Emergencies for Family Medicine Training. Teach Learn Med 2013; 25: 207-210. DOI: 10.1080/ 10401334.2013 .797353

7. Deering S, Rowland J. Obstetric emergency simulation. Semin Perinatol 2013; 37: 179-188. DOI: 10.1053/j.semperi. 2013.02 .010

8. Daniels K, Erickson L, Andreatta PB, Pliego JF, Goffman D. Simulation-based team training in obstetric emergencies. Contemp Ob Gyn [Internet]. Advanstar Communications Inc; 2012 [cited 2017 Apr 12]; Available from: http:// contemporaryobgyn.modernmedicine.com/contemporaryobgyn/news/modernmedicine/modern-medicine-now/simulationbased-team-training-obstetric-?page $=$ full

Rom J Anaesth Int Care 2017; 24: 5-6 